\title{
The Battle for Post-Habsburg Trieste/Trst: State Transition, Social Unrest, and Political Radicalism (1918-23)
}

\author{
Marco Bresciani \\ Department of Political and Social Sciences, University of Florence, Florence, Italy \\ Email: marco.bresciani@unifi.it
}

\begin{abstract}
In spite of the recent transnational turn, there continues to be a considerable gap between Fascist studies and the new approaches to the transitions, imperial collapses, and legacies of post-World War I Europe. This article posits itself at the crossroads between fascist studies, Habsburg studies, and scholarship on post1918 violence. In this regard, the difficulties of the state transition, the subsequent social unrest, and the ascent of new forms of political radicalism in post-Habsburg Trieste are a case in point. Rather than focusing on the "national strife" between "Italians" and "Slavs," this article will concentrate on the unstable local relations between state and civil society, which led to multiple cycles of conflict and crisis. One of the arguments it makes is that in post-1918 Trieste, where the different nationalist groups contended for a space characterized by multiple loyalties and allegiances, Fascists claimed to be the movement of the "true Italians," identified with the Fascists and their sympathizers. Accordingly, while targeting the alleged enemies of the "Italian nation" (defined as "Bolsheviks," "Austrophiles," and "Slavs"), they aimed to polarize the Italian-speaking community along different political fault lines to reconfigure relations between the state and civil society.
\end{abstract}

Keywords: Post-Habsburg transition; violence; postwar crisis; social conflict; political radicalism; Fascism

\section{The Stormy Summer of 1920}

Late in the afternoon of 13 July 1920, a demonstration of roughly two thousand people took place in the main square of Trieste/Trst, which had just been renamed Piazza Unità d'Italia (Italian Unity Square). The event was organized by the local Fascist movement (Fascio di combattimento di Trieste) and Italian-speaking nationalist groups ( partiti nazionali) and was triggered by the news of bloody skirmishes between Italian soldiers and "Slavic" groups in Spalato/Split two days earlier. During a public speech made by Francesco Giunta, leader of the Fascist movement in Trieste, an "Italian citizen" was stabbed to death by someone who was immediately identified as a "Slav." This rumor quickly sparked "vibrant unrest and exasperation." Some demonstrators, led by the Fascists, ran to Piazza Oberdan and began shouting at the people in the Narodni Dom (the "Slavic" National Hall, also known as the Balkan Hotel). While the Royal Guards (Guardie Regie di Pubblica Sicurezza, est. 1919-22) that were deployed around the building tried unsuccessfully to quell the demonstrators' protests, a group of Fascists, with the support of Italian soldiers, set the Narodni Dom alight and prevented the firefighters from intervening. Fleeing the blaze, a man jumped from the building to his death, and his daughter was severely injured.

Meanwhile, the city center was at the mercy of the Fascist squads late into the night. Some attempted to devastate the publishing house of the Slovenian newspaper Edinost, while others stormed private buildings and shops supposedly belonging to "Slavs." Two alleged "Slavic" banks suffered looting attempts. The Fascists also tried to storm the offices of Il Lavoratore, a Socialist newspaper they claimed was "Bolshevik," but the Italian police finally managed to stop them. ${ }^{1}$

\footnotetext{
${ }^{1}$ Recording of a telephone conversation between the Regio Commissariato Generale Civile della Venezia Giulia (Royal Civil General Commissioner's Office of Julian March) and the prime minister, no. 9474, Trieste, 14 July 1920, Archivio Centrale dello 
The narrative of these events is omnipresent in studies tracking the spread of Fascism in the northern Adriatic, and most of this historiography has taken for granted the divisions between different national communities, understanding the episode as part of the conflict between "Italians" and "Slavs." Notably, it has often uncritically echoed the language of the time, using labels like "Italian" and "Slav," as well as "Bolshevik" (bolscevico), "Slavic-Bolshevik" (slavo-bolscevico), and "Austrophile" (austriacante) as if they were self-explanatory. ${ }^{2}$ As this article will try to demonstrate, however, the rhetorical devices used by newspapers, police reports, and memoirs to portray the main actors of these disputes-the "Italian citizens," "Slavs," and "Bolsheviks"-failed to provide an accurate account of the dynamics of action and (self-)identification. In fact, the Fascio di combattimento, a relatively small yet well-organized group that claimed both to voice the fears and frustrations of the "Italian people of Trieste" and to act in their name, made the attack on the Narodni Dom. It was an overwhelmingly symbolic event, designed to put "on stage" the clash between "Italians" and "Slavs" on the northern Adriatic shores. ${ }^{3}$

The Narodni Dom was a symbol of Habsburg multinational Trieste, a cultural, social, and economic landmark for the "Slavic" community of the Adriatic town (i.e., especially the Slovenian-, but also the Serbian-, Croatian-, and Czech-speaking communities). As the Fascist propaganda fanned, the attack against it represented the primordial matrix of squadrismo - that is, the Fascists' organization of paramilitary violence-and marked the beginning of anti-Slavic attacks in the Upper Adriatic region. In the following days, the Narodni Dom in Pola/Pula and other "Slavic" and "Bolshevik" headquarters, circles, and offices in the northern Adriatic were destroyed. ${ }^{4}$ The real targets and purposes of the events of 13 July were summed up in a list of demands for the implementation of "a resolute policy of national defense" that was published a couple of days later by the Fascist newspaper Il Popolo di Trieste. Notably, it demanded "the rational and systematic cleansing of the town and of the small towns located in the armistice area, with the cooperation of citizens from any social class but of clear national faith." Only in this way would Italy be able "to protect itself from the plots hatched against it both abroad and internally by foreigners." 5

This article posits itself at the crossroads between fascist studies, Habsburg studies, and scholarship on post-1918 violence. Studies of fascism have long been constrained within national frameworks and only recently have taken a more transnational approach, revealing the cross-border intertwining ofand connections between-diverse fascist models and practices. ${ }^{6}$ However, this shift in focus has yet to impact our understanding of Italian Fascism: its origins in the period between 1919 and 1923 are still framed within a purely national context. Furthermore, there continues to be a considerable gap between fascist studies and the new comparative and transnational approaches to the transitions, imperial collapses, and legacies of post-World War I Europe. Scholars have emphasized that in the regional demobilization process, residents from postimperial border regions were considerably more likely to

Stato di Roma (Central State Archives of Rome, hereafter ACS), Presidenza del Consiglio dei Ministri (Prime Minister's Office, hereafter PCM), Ufficio Centrale per le Nuove Province (Central Department for the New Provinces, hereafter UCNP), busta 50. The first time they appear, the names of towns are reported in multiple languages, after which the official name at the time is used.

${ }^{2}$ Renzo De Felice, Mussolini il rivoluzionario (1883-1920) (Turin, 1965), 624; Elio Apih, Fascismo e antifascismo nella Venezia Giulia (Bari, 1966); Almerigo Apollonio, Dagli Asburgo a Mussolini. Venezia-Giulia 1918-1922 (Gorizia, 2002); Milica Kacin-Wohinz, Vivere al confine: sloveni e italiani 1918-1941 (Gorizia, 2004); Kacin-Wohinz, Alle origini del fascismo di confine: gli sloveni della Venezia Giulia sotto l'occupazione italiana 1918-1921 (Gorizia, 2010); Marina Cattaruzza, L'Italia e il confine orientale (Bologna, 2007); Darko Dukovski, Fašizam u Istri (Pula, 1998); Jože Pirjevec, Trst je naš!: boj Slovencev za morje (1848-1954) (Ljubljana, 2007); Anna Maria Vinci, Sentinelle della patria. Il fascismo al confine orientale (Rome, 2011).

${ }^{3}$ This approach is partly inspired by Max Bergholz, Violence as a Generative Force: Identity, Nationalism, and Memory in a Balkan Community (Ithaca, 2016).

${ }^{4}$ Matteo Di Figlia, “Dimenticare il 'Balkan': la distruzione del Narodni Dom di Trieste nelle rielaborazioni fasciste (19211941)," Qualestoria 44, no. 2 (2016): 7-23.

5“Appelli," 15 July 1920, in Francesco Giunta, Un po’ di fascismo (Milan, 1935), 28-30.

${ }^{6}$ Antonio Costa Pinto and Aristotle Kallis, eds., Rethinking Fascism and Dictatorship in Europe (Basingstoke, 2014); Arnd Bauerkämper and Grzegorz Rossoliński-Liebe, eds., Fascisms without Borders: Transnational Connections and Cooperation between Movements and Regimes in Europe from 1918 to 1945 (New York, 2017). 
engage in paramilitary activity than those from more peaceful parts of the continent. ${ }^{7}$ In what ways, and to what extent, does this revision of Habsburg studies and of the studies on postwar violence impact our understanding of political radicalism, and notably of fascism, in interwar Central Europe?

For more than two decades works on the Central European borderlands have critically questioned those narratives that take nationalism and its grip on local societies for granted. Recent studies have focused on contingent and situational forms of identification, which suddenly crystallize claims of not only national but also imperial, regional, or municipal belongings. These forms of identification correspond to "categories of practice," in the words of sociologist Rogers Brubaker. ${ }^{8}$ As Tara Zahra and Pieter Judson suggest, a special emphasis on "national indifference" helps to revise those narratives based exclusively on nationalist activists and conflicts and to investigate limits and contradictions in the nationalizing processes. Although the term "national indifference" may be controversial-deemed a catchall term including too many different practices and attitudes-this article assumes that the northern Adriatic after the collapse of the Habsburg Empire was marked by multiple forms of local and regional loyalism, bilingualism, multiculturalism, and internationalism. ${ }^{9}$

One of the arguments this article makes is that in post-Habsburg Trieste, where the different nationalist groups contended for a space characterized by multiple loyalties and allegiances, Fascists claimed to be the movement of the "true Italians," identified with the Fascists and their sympathizers. Fascism clearly had nationalistic purposes, and as such it targeted the alleged enemies of the "Italian nation." At the same time, however, it aimed to polarize the Italian-speaking community along different political fault lines. The Fascists' actions and plans were thus ideologically driven and appropriated the language of Italian nationalism in addition to other means of mobilization. The attack on the representatives and symbols of the "Slavs" in Trieste and elsewhere in the northern Adriatic was part and parcel of a broader offensive against "foreigners" (stranieri), "Bolsheviks," and "Austrophiles." These quite arbitrary categories were nonetheless dramatically effective in their emotional "loadedness" and were used both to classify the alleged enemies of the "Italian nation" and to legitimize the Fascist movement, which aimed to reconfigure relations between the state and civil society.

Rather than focusing on the "national strife" between "Italians" and "Slavs," I will thus be concentrating on the unstable local relations between state and civil society in post-Habsburg Trieste, which led to multiple cycles of conflict and crisis. I shall adopt a situational perspective both to observe the contingent dynamics set in motion by state and nonstate actors and to understand what arguments were used by the region's political movements and cultures to mobilize social groups and legitimize violent practices by opposing one another and competing for the formation of a "new order."

\section{Unexpected Difficulties in the Regime Change}

Given imperial city status in 1849, Trieste had been the fourth-largest city of the Austro-Hungarian Empire (after Vienna, Budapest, and Prague) and the empire's most important seaport, thanks to the development of port infrastructure and the building of railway links during the second half of

\footnotetext{
${ }^{7}$ Robert Gerwarth and John Horne, eds., War in Peace: Paramilitary Violence after the Great War (Oxford, 2012); Jochen Böhler, Włodzimierz Borodziej, and Joachim von Puttkamer, eds., Legacies of Violence: Eastern Europe’s First World War (Munich, 2014); Gerwarth, The Vanquished: Why the First World War Failed to End, 1917-1923 (London, 2016).

${ }^{8}$ This approach is based on Rogers Brubaker and applies or extends his approach to nationalism to fascism. Brubaker, "Rethinking Nationhood: Nationhood as an Institutionalized Form, Practical Category, Contingent Event," in Nationalism Reframed: Nationhood and National Question in the New Europe, ed. Rogers Brubaker (Cambridge, 1996), 18-22.

${ }^{9}$ For other aspects see Marco Bresciani, "The Upper Adriatic Space and the Post-War Ascent of Fascism," in Vergangene Räume - Neue Ordnungen. Das Erbe der multinationalen Reiche und die Staatsbildung im östlichen Europa 1917-1923, ed. Tim Buchen and Frank Grelka (Frankfurt Oder, 2017), 47-64; and Bresciani, "Lost in Transition? The Habsburg Legacy, State- and Nation-Building, and the New Fascist Order in the Upper Adriatic," in National Indifference and Nationalism in Modern Europe, ed. Maarten Van Ginderachter and Jon Fox (London, 2019), 56-80. More generally, see Glenda Sluga, The Problem of Trieste and the Italo-Yugoslav Border: Difference, Identity, and Sovereignty in Twentieth-Century Europe (Albany, 2002); Rudolf Wörsdörfer, Krisenherd Adria 1915-1955: Konstruktion und Artikulation des Nationalen im italienischjugoslawischen Grenzraum (Paderborn, 2004); Marta Verginella, Il confine degli altri: la memoria giuliana e la questione slovena (Rome, 2008); Dall'Impero austro-ungarico alle foibe. Conflitti nell'area alto-adriatica (Turin, 2009).
} 
the nineteenth century. Like many other Central European cities, Trieste offered a multilinguistic urban setting. According to the 1910 census, based on the language of everyday use (Umgangssprache), out of a total population of 229,510 residents the local Italian speakers numbered around 119,000; the Slovene speakers 56,916; the German speakers 11,856; and the Serbian-Croatian speakers 2,403. More than half the population of Trieste was born elsewhere. A significant presence in the city were the 38,597 regnicoli or Reichsitaliener-a specific classification of immigrants who had Italian citizenship. The social and cultural reality of prewar Trieste was much more blurred and fluid than the rigid national categorization imposed by the census might suggest. While being ruled by the Italian National-Liberal (nazional-liberale) Party and challenged by the increasingly popular Slovenian-speaking nationalist groups, this active port town on the road to industrialization acted as a catalyst for immigrants coming from the countryside (the surroundings of Trieste, as well as from Contea principesca di Gorizia e Gradisca/Poknežena grofija Goriška in Gradiščanska/Gefürstete Grafschaft Görz und Gradisca, Carinzia/Kärnten/Koroška, and Carniola/Krain/Kranjska). These contributed to a growing working class, as witnessed by the rise of the Socialist movement in the city. Most of the workers, often considered "of Slavic nationality," lived in the outskirts of the old town in Servola/ Škedenj, San Giacomo/Sveti Jakob, Zaule/Žavlje, Rozzol/Rocol, Guardiella/Vrdela, Roiano/Rojan, Gretta/Greta, or Barcola/Barkovlje. ${ }^{10}$

The war marked a major disruption between the imperial state and local society in Trieste, as elsewhere. Its population, 243,415 in 1914, decreased to approximately 152,740 in 1917 for a number of reasons: many young people were called to arms; several factories, enterprises, banks, and insurance companies were transferred (together with their workers and employees) to regions far away from the front line; most of the regnicoli returned to Italy when war broke out; and 1,047 local people volunteered for the Italian army. Allegedly disloyal irredentists or Socialists were imprisoned (approximately 350 to 500). Those regnicoli who had remained in town were interned (approximately 2,900 ), exiled (approximately 1,800 ), or forcefully repatriated (approximately 9,800). ${ }^{11}$ These repressive wartime measures, especially implemented between 1915 and 1916, testified to the imperial institutions' growing distrust of the loyalty of the local populace. Fear and suspicion were fed by the anonymous denunciations of alleged traitors for both private and political reasons, thus contributing to the increasing breakdown of social relations. ${ }^{12}$

During the last year of the war, insufficient food supplies, severe economic decline, and massive unemployment dramatically affected the city's population, which increasingly distrusted the everyday efficiency of the imperial administration. Unlike other Habsburg cities, Trieste, in spite of its depressing conditions, saw no uprising take place until the very last moment, when, following the military defeat at Vittorio Veneto (24 October 1918), the empire's institutions began to crumble. On 31 October, in the midst of the regime change, the town was the scene of rioting: the mob, including many former prisoners of war, looted shops and warehouses at the port and clashed with the civil guard. In the absence of stable, legitimate institutions, the provisional authorities had to provide food, take control of the railways, and guarantee public order. ${ }^{13}$ In fact, the awareness of the

\footnotetext{
${ }^{10}$ Marina Cattaruzza, La formazione del proletariato urbano: immigrati, operai di mestiere, donne a Trieste dalla metà del secolo 19. alla prima guerra mondiale (Turin, 1979); Cattaruzza, Trieste nell'Ottocento: le trasformazioni di una società civile (Udine, 1995); Roberto Finzi and Giovanni Panjek, eds., Storia economica e sociale di Trieste, I, La città del gruppi, 1719-1918 (Trieste, 2001).

${ }^{11}$ Lucio Fabi, Trieste 1914-1918. Una città in guerra (Trieste, 1996); Franco Ceccotti, ed., "Un esilio che non ha pari": 19141918, profughi, internati ed emigrati di Trieste, dell'Isontino e dell'Istria (Gorizia, 2001); Elena Tonezzer and Stefan Wedrac, "Die Italiener des Österreichischen Küstenlandes, Dalmatiens und des Trentino," in Die Habsburgermonarchie 1848-1918, XI/1: Die Habsburgermonarchie und der Erste Weltkrieg. Der Kampf um die Neuordnung Mitteleuropas, vol. 2, ed. Helmut Rumpler, Harald Heppner, and Erwin A. Schmidl (Vienna, 2016), 919-64.

${ }^{12}$ In general, see Laurence Cole, Military Culture and Popular Patriotism (Oxford, 2014), 217-67; Cole, "Questions of Nationalization in the Habsburg Monarchy," in Nations, Identities, and the First World War, ed. Nico Wouters and Laurence Van Ypersele (London, 2018), 115-34; Tamara Scheer "Denunciation and the Decline of the Habsburg Home Front during the First World War," European Review of History: Revue européenne d'histoire 24, no. 2 (2017): 214-28.

13"La presa di possesso della città," La nazione, 1 Nov. 1918, in Trieste, Ottobre-Novembre 1918. Raccolta di documenti del tempo a cura di S.F. Romano, parte I, Gli ultimi giorni della dominazione austriaca (Milan, 1968), 156-57.
} 
complexities of the "so-called period of transition between war and peace" quite soon emerged among Trieste's intellectuals, journalists, and political commentators. "The period of transition after a war like this," wrote the Triestine Italian-leaning daily La Nazione in early December 1918, "is necessarily one of the hardest ones: even it has no parallel with the start itself of the state of war." "14

Local political elites played an important role in the contingencies of the regime change well before the Italian troops and authorities appeared on the scene. On 23 October, the National Council of Slovenes, Croats, and Serbs (Narodno vijeće Slovenaca, Hrvata i Srbal Narodni svet Slovencev, Hrvatov in Srbov; hereafter SHS), based in Zagreb and Ljubljana, issued a decree calling for the establishment of local committees (including in Trieste) to be entrusted with helping and defending the empire's "Slavic" populations. ${ }^{15}$ Yet the real transition to the post-Habsburg order started on 28 October, when an Italian National Fascio (Fascio Nazionale Italiano) was self-proclaimed; two days later, on its own initiative, it instituted a Committee of Public Safety (Comitato di Salute Pubblica) composed of twelve members of the Fascio and twelve members of the Socialist Party. When a number of irredentist demonstrations took place, the Fascio formally asked the Austrian lieutenant (Statthalter) Alfred von Fries-Skene for the transfer of public powers, and this was officially approved by Heinrich Lammasch, the last minister-president of Cisleithania. However, a major sign of institutional and personal continuity with Trieste's Habsburg past was given when Alfonso Valerio, an Italian-speaking lawyer and a typically pre-1914 liberal and irredentist politician who had served as mayor (podesta) of Trieste between 1909 and 1915, was appointed the first head of the Fascio and was then reconfirmed as the first citizen.

The Italian occupation, begun on 3 November 1918, was ruled by the military authority (Governatorato militare) under General Carlo Petitti di Roreto, but its legitimacy was far from being undisputed at the local level. The Committee for Public Safety was thus asked to quell any kind of social unrest by incorporating "citizens of different nationalities." ${ }^{16}$ For this purpose, four members of the Slovenian Club (two nationalists and two Socialists) were integrated into the Committee for Public Safety, but no other representative of the diverse population of Trieste was included. From the outset the Italian authorities thus tended to ignore the multicultural and multilinguistic composition of Triestine society and immediately treated it in dualistic terms of "Italians" and "Slavs." For example, even the prime minister Vittorio Emanuele Orlando asked General Armando Diaz "to conciliate the just establishment of military rule with all possible respect toward the Slavs." 17 Within a few weeks, however, there was increasing unrest and the first signs of potential conflict. In an appeal to the Italian authorities, the local committee of the National Council of SHS requested permission to use the Slovenian language in its schools, post offices, railways, and public life on the basis of the equality of Slovenian-speaking people from Trieste with the town's Italian citizens. Nevertheless, on 23 November General Carlo Petitti di Roreto disbanded the National Council of SHS, fearing that the organization could legitimize the territorial claims of the State of Slovenes, Croats, and Serbs officially established on that same day (from 1 December onward, renamed the Kingdom of Serbs, Croats, and Slovenes, hereafter SHS). Additionally, he passed a decree that suspended postal, telegraph, and telephone communications with the former Austro-Hungarian lands beyond the line of the armistice and interrupted railway service to and from Vienna. In many ways, local actors and their demands were losing the critical importance they had in the early transitional period, and the occupational forces were imposing themselves in an effort to make Trieste Italian. However, perceptions of the ongoing transition differed. On the one hand, for instance, the bishop of Trieste Andrea Karlin-born in Stara Loka (close to Ljubljana), appointed in 1911, and loyal to

\footnotetext{
14"Il periodo di transizione," La Nazione, 1 Dec. 1918.

${ }^{15}$ For further information see Ivo Banac, The National Question in Yugoslavia: Origins, History, Politics (Ithaca, 1984), 127-38.

${ }^{16}$ Appeal to the people of Trieste by the Comitato di Salute Pubblica (Committee for Public Safety), 30 Oct. 1918, in Trieste, Ottobre-Novembre 1918, parte I, 150-51. A similar invitation was issued by Edinost, 31 Oct. 1918, in Trieste, Ottobre-Novembre 1918, parte I, 153-54.

${ }^{17}$ Instructions from Vittorio Emanuele Orlando to Armando Diaz, 3 Nov. 1918, in Trieste, Ottobre-Novembre 1918. Raccolta di documenti del tempo a cura di S.F. Romano, parte II, Gli inizi del Governo Militare Italiano (Milan, 1968), 22.
} 
the empire-in his journal entry dated 27 November, portrayed the dramatic shift that the annexation of the Upper Adriatic to Italy implied in terms of both sovereignty and identity: "I am sorry that we are now cut off from the rest of the world. Mail is no longer delivered from Ljubljana or Vienna, but from Sicily and Calabria. It is clear that we are hopelessly Italian." ${ }^{18}$ On the other hand, as early as late November 1918 the feeling that "all life's mechanisms could change overnight" quickly waned. According to La Nazione, time was needed "for the life of these lands to adapt to the new mechanisms and to connect the town with the national communications networks." 19

While disconnecting Trieste from the former Habsburg hinterland, a series of administrative provisions aimed to appropriate and nationalize the city's public sphere, as in other post-Habsburg multilingual urban settings. This was the first act of the city council's inaugural meeting, held on 11 November 1918, and was in response to the name changes made by wartime Austria. To erase the memory of the empire and provide a clear nationalization of the public realm, previous names of streets and squares were replaced with names linked to recent Italian history. For instance, Piazza Grande was renamed Piazza Unità d'Italia; Riva Demetrio Carciotti (an eighteenth-century Greek merchant) was renamed Riva 3 Novembre (armistice day); Piazza della Caserma became Piazza Guglielmo Oberdan (an Italian irredentist from Trieste suspected of terrorism and executed in 1882); Riva dei Pescatori was changed to Riva Nazario Sauro (after the Italian irredentist from Capodistria/Koper who switched sides and enrolled as a volunteer in the Italian navy and was subsequently taken prisoner, accused of treason, and executed in 1916); Stadion Street was renamed after Cesare Battisti (a Socialist irredentist from Trento who changed sides and enrolled as a volunteer in the Italian army and was similarly taken prisoner, accused of treason, and executed in 1916). ${ }^{20}$

If the Italianization of Trieste's toponyms was quite easy, efforts to nationalize the post-Habsburg public administration soon reverberated with all the uncertainties and tensions of the transition. In early November the military authorities asked for a complete list of the names of the municipality's employees. However, all employees who had been temporarily banned, retired, or dismissed for political reasons during the war were reinstated or asked to resume their posts on the basis of a provision dated 16 November $1918 .{ }^{21}$ At the same time, ex-Habsburg employees and officials had to submit individual applications for the confirmation of their role in the Italian administration. ${ }^{22}$ Then, on the basis of a decree issued by the High Command on 29 November, the new authorities were requested to detain "politically untrustworthy subjects" and to send back "subjects not belonging to the currently occupied lands who are suspected of having recently immigrated." ${ }^{23}$ However, some of them applied to be reemployed by professing their loyalty to the new authorities. For example, if we examine the case of the Royal Port Authority (Regio Governo Marittimo), we see that thirty-seven officials and employees (including eleven women) had been fired from their jobs by mid-December 1918 and forced to leave the armistice area. Some of them applied for reinstatement in the new Italian administration or for an Italian pension, as well as for residency in Trieste. For example, Giulio Löbenhöfer, a port authority employee from Budapest who had been granted legal Heimat rights (Heimatrecht, pertinenza) in Trieste in 1892, stated:

\footnotetext{
${ }^{18}$ Antonio Scottà, ed., I territori del confine orientale italiano nelle lettere dei vescovi alla Santa Sede (Trieste, 1994$), 197$.

19“Gli eredi dell'Austria," La Nazione, 23 Nov. 1918.

${ }^{20}$ See Paolo G. Parovel, L'identità cancellata. L'italianizzazione forzata dei cognomi, nomi e toponimi nella "Venezia Giulia” dal 1919 al 1945 (Trieste, 1985); Maura Hametz, “The Nefarious Former Authorities: Name Change in Trieste, 1918-1922,” Austrian History Yearbook 35 (2004): 233-52; Hametz, Making Trieste Italian, 1918-1954 (Woodbridge, 2005).

${ }^{21} 1918$, file no. 28: Governor's Office asks for a list of names of all the staff in 1909-18, Dirigenza (Management), Carteggio (Correspondence); 1918, file no. 524: Reinstatement of the employees dismissed in Sezione II, Personale (Staff), Archivio Comunale, Trieste.

${ }^{22}$ Decree of the Regio Governatorato della Venezia Giulia (Royal Governor's Office of Julian March), 12 Nov. 1918, in L'osservatore triestino. Giornale ufficiale del Regio Governatorato.

${ }^{23}$ Decree of the High Command of the Third Army, Section General Affairs, 29 Nov. 1918, Archivio di Stato di Trieste (State Archive of Trieste, hereafter AST), Regio Commissariato Generale Civile della Venezia Giulia (Royal Civil General Commissioner's Office of Julian March, hereafter RCGCVG), Atti di Gabinetto (Acts of Cabinet, hereafter AG), busta 12, quoted in Vinci, 21.
} 
Since I have been granted these legal Heimat rights, it is totally impossible for me to request hospitality in my native city of Budapest or in any other town in Hungary, as I can no longer be considered a Hungarian citizen. For the same reason, any other municipality of the former Austrian Empire may reject me, and thus I risk being driven away from one place to the next, of being sent back to Trieste, my homeland. ${ }^{24}$

Another example is Francesco Kminek, a retired employee at the chancellor's office of the Maritime Government, who asked to be allowed to stay in Trieste. Born in Bohemia in 1865, he spent most of his life between Pola, Fiume, and Trieste, where he had been granted legal Heimat rights since 1898. His wife, born in Trieste, was "from Italian nationality," and his family, composed of four children, spoke the Italian language: "among his family members nobody understands the Czechoslovak language and his entire family wishes to stay forever in Trieste, as its homeland." 25 Trieste as "homeland" (patria) is a key passage in most of these documents, revealing both the crucial importance of the local dimension in the self-identification of public officials, as well as its use in replacement of national categorization. From the sources it is not clear if Giulio Löbenhöfer and Francesco Kminek, like others, were finally reinstated into the local administration and given the permission to live in Trieste or were expelled. To be sure, in some cases pragmatism prevailed to guarantee administrative continuity and efficiency. For instance, Nicolò Marinović, born in Ragusa/Dubrovnik, of "Serbian nationality and political sentiments," who spoke Italian "well" and "always kept very correct behavior vis-à-vis the Italian nationality," was confirmed as high legal commissioner in the port authority. Similarly, the high construction inspector Francesco Austigal, born in Linz, "of German nationality," "with several years of legal residence (domiciliato) in Trieste," who spoke Italian "sufficiently" and "always kept very correct behavior vis-à-vis the Italian nationality," was confirmed as bookkeeper for the port authority of Trieste. ${ }^{26}$ In sum, no consistent criteria were established for the national purge of the local administrative bodies. Knowledge of "Slavic" languages was insufficient reason for someone to be excluded, even though such knowledge was often considered politically suspicious by the Italian authorities. Nor was proof of possession of the ex-Habsburg legal Heimat rights in the armistice area deemed a reliable reason for confirming the employees in the new administrative bodies. Regardless of their "nationality," a certain number of officials and employees of post offices, railway networks, and town administrations who were considered as potentially disloyal to the Italian state (as "of anti-Italian sentiments" or "adverse to our institutions") were dismissed and expelled from the armistice area. However, as partial and selective as they might be, these policies produced a general sense of pending legal, professional, and existential insecurity. ${ }^{27}$

Postwar Trieste underwent further population changes when thousands of German-speaking and "Slavic"-speaking people migrated toward Austria or the Kingdom of SHS, while it recovered its prewar demographic levels thanks to immigration from Italy (above all from Veneto, including at that time also Friuli). Up to thirty-nine thousand former regnicoli came back to Trieste over the course of 1919, despite that their properties had been destroyed or transferred to someone else due to their unpopularity with the local population. Additional migrants from Italy went to the industrialized

\footnotetext{
${ }^{24}$ Petition of Giulio Löbenhöfer to the Royal Governor's Office of Julian March, 8 Dec. 1918, AST, RCGCVG, AG, busta 146. The personal names are transcribed as they were reported in the document.

${ }^{25}$ Petition of Francesco Kminek to the Royal Governor's Office of Julian March, 17 Dec. 1918, AST, RCGCVG, AG, busta 146. The personal names are transcribed as they were reported in the document.

${ }^{26}$ Justifications for the exceptions in lists 2 and 3, AST, RCGCVG, AG, busta 146. The personal names are transcribed as they were reported in the document.

${ }^{27}$ For further considerations see Maura Hametz, "Uncertain States: Repatriation and Citizenship in the Northeastern Adriatic, 1918-1921," Acta Histriae 21, no. 4 (2013): 791-808; and Hametz, "Stateless in Italy? The Post-World War I Triestine Citizenship Commission," Contemporanea 22, no. 1 (2019): 79-96. As for the definition of Heimatrecht or pertinenza, see Pieter Judson, "Citizenship without Nation? Political and Social Citizenship in the Habsburg Empire," Contemporanea 21, no. 4 (2018): 633-46.
} 
areas of the town in search of jobs. ${ }^{28}$ As a police informer reported in March 1920, the local workers and public employees complained that many of them were still unemployed and were placed second to regnicoli: "Someone added that the Austrian Government showed more sympathy for the Triestine people and more trust in their capacity and loyalty." $" 9$

If one aims to understand post-Habsburg Trieste, this popular mood fostered by postwar everyday needs and difficulties should not be underestimated. Economic decline and massive unemployment, the administrative inefficiency of the new authorities, an inflow of new administrators and workers from other regions competing with the locals-all this together fed an instinctive comparison with the Habsburg past and subsequent dissatisfaction with the Italian present. Hence the retrospective nostalgia for the "world of yesterday," which did not necessarily equate to a "reactionary" stance vis-à-vis Habsburg institutions and policies or directly transform into a "revolutionary" critique of the Italian state as such. ${ }^{30}$ Nevertheless, polemics against "Austria" and "Austrophiles" and charges of "Austrophilism" (austriacantismo) quickly became nationalist weapons against the alleged "enemies within." For instance, according to the nationalist journalist and historian Attilio Tamaro, Trieste continued to be a seedbed of "Austrophiles" who were "loyal to the former Monarchy with a spirit of servitude" or in view of their "shared interests." ${ }^{31}$ More sharply, the Fascist journalist Gino D'Angelo argued that "It is rather naive and incautious to assert that Austria has disappeared from Trieste." 32 "Austrophilism," as the Fascist leader Giunta put it, "smoldering in gentlemanly social gatherings and in sordid dives, in the halls of high finance and in ships' holds, in public offices and in the courts, at the stock exchange and in churches, unfolds with varying intensity. It is usually a murmured, cautious work of slander, a defeatist whisper, spiced with sighs and regret, an annoying insensitive invective that erupts in choleric outbursts barely contained by fear."33

In these views, the process of Italianization was deemed too slow and rather ineffective in rooting out and removing the "Austrophiles" from Trieste's bureaucratic and economic system. The aggressive and obsessive blame placed on "Austrophilism" was a powerful rhetorical resource, exceptionally effective in legitimizing policies of retaliation and in self-legitimizing social careers. From the Italian nationalists' point of view, "Austrophilism" covered a very broad range of attitudes and behaviors, including physically violent attacks on officials of the Italian state, loud "Bolshevik" or "Slavic" propagandistic campaigns, or simply whispered criticism of the new Italian authorities. The charge of being an "Austrophile" intersected with those of being "Bolshevik" or "Slavic," but the former was potentially even more flexible and extensive than the latter as it pervaded the entire local society and represented a driver of communal polarization. "The people of Trieste," the bishop Karlin noted in his diary on 12 November 1919, "are becoming increasingly aggressive. It is clear that they will seek to whitewash any memory of previous Austrian power and all trace of any Yugoslav presence."34

To counter this local animosity and to stabilize the political and social situation, the Italian state implemented contradictory policies-one pushing toward the process of centralization, the other attempting to slow it down. In July 1919, the military authority was then replaced by a civil authority (Commissariato Generale Civile della Venezia Giulia), headed first by Augusto Ciuffelli and then by Antonio Mosconi. The latter, a state administrator who hailed from a patriotic family of Vicenza and acted as the representative of the central government in Trieste, relentlessly attempted to integrate the new provinces into the centralized institutions and conform their rule to the national laws. At the

\footnotetext{
${ }^{28}$ For the number of regnicoli see Ceccotti, "Un esilio che non ha pari," 64. More generally, see Piero Purini, Metamorfosi etniche. I cambiamenti di popolazione a Trieste, Gorizia, Fiume e in Istria. 1914-1975 (Udine, 2010). According to Purini, out of 11,856 German-speaking people, 3,700 remained in the early 1920s.

${ }^{29}$ Report of the Ministero dell'Interno, Direzione Generale Pubblica Sicurezza, Divisione Affari Generali e Riservati, 29 Mar. 1920, to Francesco Salata, head of the Central Department for the New Provinces, ACS, PCM, UCNP, busta 61.

${ }^{30}$ See the memoirs by Rodolfo Ursini-Uršič, Attraverso Trieste. Un rivoluzionario pacifista in una città di frontiera (Rome, 1996), 14-15.

${ }^{31}$ Angelo Tamaro, “Casi e aspetti del socialismo a Trieste," Il Piccolo, 6 Nov. 1919.

${ }^{32}$ Gino D’Angelo, "In tema di violenza," Popolo di Trieste, 3 Mar. 1921.

${ }^{33}$ Francesco Giunta, "Ingratitudine," Popolo di Trieste, 11 Oct. 1921.

${ }^{34}$ Scottà, ed., I territori, 194.
} 
same time, a Central Department for the New Provinces (Ufficio Centrale per le Nuove Province) was set up in Rome, headed by Francesco Salata, a historian and politician from the island of Cherso/Cres and a liberal irredentist who had carried out his administrative career in Habsburg Istria by embodying the Austrian tradition of self-government. Accordingly, Salata drafted a transitional normative model on the basis of which the validity of the previous Habsburg legal system was confirmed at local level, albeit with a notable proviso: at the moment of formal annexation, those provisions of the Habsburg legal system that conflicted with Italian public law could be repealed, while laws from the Italian legal system could be introduced and supplemented. ${ }^{35}$ In tune with Salata's approach, a decree of 4 July 1919 prevented "any levelling and assimilating policy" in the new provinces "to respect their laws, special conditions, customs, and traditions." 36

In post-Habsburg Trieste, as in all Central Europe, the points of departure and the lines of continuity were closely interwoven. ${ }^{37}$ In spite of attempts at stabilization, one year after the Italian military occupation, the political and social climate in Trieste was one of tension and uncertainty. In a way, "the transition from the now finished past to the new nationalist present was, externally, hardly perceptible," as the jurist, historian, and liberal politician Joseph Redlich argued. ${ }^{38}$ Nevertheless, it was exactly this perception of continuity that contributed to making the battle for the post-Habsburg northern Adriatic city ever more difficult.

\section{Social Conflict and the Rise of Socialist Radicalism}

As we have seen, the new authorities and the Italian nationalist groups reproached the Socialists for having supported Austria, "an enemy of Italianness." The Socialists' critical stance toward the new authorities and their multinational perspective tended to credit the image of the Italian Socialist Party as being a bulwark of "Austrophilism" and a point of reference for all former loyalists as well as for the "Slavs." However, this representation retrospectively reframed the critical relationship of the Austrian Social Democrats toward the imperial state and its opposition to the war and to the wartime repression. Not surprisingly, a completely opposite picture was painted by the local Socialist newspaper Il Lavoratore. In its view, the real "Austrophiles" were the bourgeoisie and the capitalists, a "yellow-black gang" who had supported first the empire and its war effort and now took up the cause of the Italian nationalists and Fascists. ${ }^{39}$ On the contrary, the Socialists, even when they considered themselves "Italians," claimed to be "first of all internationalists" who wanted "to get rid once and forever of the race hatred and nationalist manhunt." 40

The Adriatic section of the Socialist Workers' Party in Austria (Sezione adriatica del Partito socialista operaio in Austria), founded in 1902, had been part of the Social Democratic Workers' Party of Austria (Sozialdemokratische Arbeiterpartei Österreichs). Despite its acknowledgment of Italian as the official language, it promoted cooperation between different linguistic groups in accordance with the guidelines of the Socialist Congress of Brünn/Brno (1899). The Socialists constituted a real multilinguistic and multicultural force that openly used the Marxist language of class struggle; however, just like the other political forces within the region, they internalized national categories, specifically subdividing the social and cultural landscape of the Upper Adriatic in terms of the corresponding linguistic identity of the "Italians" and "Slavs." While the nationalist forces tended to

\footnotetext{
${ }^{35}$ See Ester Capuzzo, Dal nesso asburgico alla sovranità italiana. Legislazione e amministrazione a Trento e a Trieste (19181928) (Milan, 1992); and Luca Riccardi, Francesco Salata tra storia, politica e diplomazia (Udine, 2001).

${ }^{36}$ Newsletter issued by Prime Minister Francesco Nitti, 26 July 1919, in Riccardi, Francesco Salata, 285-87.

${ }^{37}$ See Pieter Judson, "Where our commonality is necessary...': Rethinking the End of the Habsburg Monarchy," Austrian History Yearbook 48 (2017): 1-21; Paul Miller and Claire Morelon, eds., Embers of Empire: Continuity and Rupture in the Habsburg Successor States after 1918 (New York, 2018). An interpretation of the Habsburg heritage in the Upper Adriatic and South Tyrol was put forward by Dennison Rusinow in Italy's Austrian Heritage (Oxford, 1969).

${ }^{38}$ Redlich was the Austrian Empire's last minister of finance. Joseph Redlich, Austrian War Government (New Haven, 1929), 167.

39"Schermaglie," Il Lavoratore, 11 Sept. 1920.

40"La via dritta," Il Lavoratore, 8 Aug. 1920.
} 
emphasize any conflict between the two categorized groups, most Italian- and Slovenian-speaking Socialists stressed the capacity of internationalism to neutralize this conflict by appealing to both "Italian" and "Slavic" workers, by considering the nation-state as corresponding to the temporary "bourgeois" stage, and by emphasizing the transformative potential of Socialist federalism. An autonomous party was organized for "Slavic" workers only-the South Slavic Social Democratic Party (Jugoslovanska Socialnodemokratska Stranka)—while the National Workers' Organization (Narodna Delavska Organizacija) tried to combine Socialism and local Slovenian nationalism.

In the postwar period, the Italian Socialist Party played an increasingly important role as the main politically organized force in the northern Adriatic region. In September 1919, the congress of the South Slavic Social Democratic Party taking place in Trieste passed a resolution to join the Italian Socialist Party. ${ }^{41}$ The leaders of this congress, Henrik Tuma, Ivan Regent, and Anton Jernejčič, had been activists within the South Slavic Social Democratic Party. After the collapse of the empire, even though they might claim to be "Slovene," they shifted to internationalist positions in an effort to overcome the national question. ${ }^{42}$ This internationalist stance was shared by the Adriatic section of the party, headed by Giuseppe Tuntar, Antonio Juraga, and Antonio Laurencich, who adhered to the "maximalist program" in 1919-in stark contrast to the reformist currents, which were in favor of the Wilsonian principle of self-determination. Both the revolutionary and the reformist currents took their inspiration from the Austro-Marxist tradition. However, the reformists continued to believe in the long-term dissemination of culture as a means by which radical social change could be achieved; the revolutionaries, however, were enchanted by the Russian Revolution and Bolshevism, and accordingly prioritized the need for immediate action-a violent one if necessary-against the new institutions. ${ }^{43}$ After being controlled by the reformist wing of the party until late 1918, the Socialist Party stood under the banner of international revolution, based on the Bolshevik model. This attracted a number of former soldiers who had been prisoners in the Russian Empire and had personally (and enthusiastically) experienced the Russian revolutions. In October 1919, even before participating in the Italian Socialist Party Congress held in Bologna, the Adriatic Socialists subscribed to the Third International and to the revolutionary program, which claimed the advent of a Soviet republic based on the Bolshevik model, advocated the use of both "violent or legal combat," and rejected the "concept of nation." 44

In addition to these ideological discussions, the Socialist Party played a major role on the ground in different social and professional environments by supporting claims for higher salaries in time of inflation and by voicing dissatisfaction with the new authorities. In a context of economic insecurity, officials and employees of the ex-Habsburg administration, working at the time on the railways, in the city's post offices, for the port authority, and for the municipality of Trieste, took part in several strikes with the support of the Socialist Party. ${ }^{45}$ For instance, a mass strike was called by the employees of the municipality in April 1920. Their salaries were still paid in Austrian currency (Krone), and because of the discrepancy with the Italian currency (lira), especially in a context of rising prices, they demanded the same economic treatment as that afforded to employees of other Italian regions. Notwithstanding the fact that basic public services (gas and water supplies, tram services, public lighting) were cut off almost completely for about one month because of the strike, there was significant public support for

\footnotetext{
${ }^{41}$ Report by the Royal Civil General Commissioner's Office of Julian March to the Prime Minister's Office, Central Department for the New Provinces, 26 Sept. 1919, AST, RCGCVG, AG, busta 56.

${ }^{42}$ See the autobiographies of Tuma and Regent: H. Tuma, Iz mojega življenja (Ljubljana, 1937) [Italian edition: Dalla mia vita. Ricordi, pensieri e confessioni (Gorizia, 1994)]; Ivan Regent, Spomini (Ljubljana, 1967).

${ }^{43}$ See in general Jakub Beneš, Workers and Nationalism: Czech and German Social Democracy in Habsburg Austria, 1890-1918 (Oxford, 2017). In particular, Giuseppe Piemontese, Il movimento operaio a Trieste: dalle origini all'avvento del fascismo (Rome, 1974).

${ }^{44}$ Elio Apih, Il socialismo italiano in Austria: Saggi (Udine, 1991); Marina Cattaruzza, Socialismo adriatico: La socialdemocrazia di lingua italiana nei territori costieri della Monarchia asburgica (1888-1915) (Manduria, 1988); Sabine Rutar, Kultur-Nation-Milieu. Sozialdemokratie in Triest vor dem Ersten Weltkrieg (Essen, 2004).

${ }^{45}$ Defense of the officials and employees of the judicial and financial administration, of the postal and telecommunications workers, operators of the maritime authority, and officials of the customs to the prime minister, Feb. 1919, AST, RCGCVG, AG, busta 3 .
} 
the strikers, who appeared to be voicing the town's discontent with the postwar political and social situation. The provisional authorities ended up meeting the strikers' demands as they considered the state administrators of the "ceased regime" as "indispensable for the public service." Additionally, they feared that this "dangerous state of exacerbation" might be "whipped up by antinational elements" attempting "to discredit the government."

Similar institutional reactions arose from the active involvement of the Socialist organizations, including the Chamber of Labor with its thirty-six thousand members, in strikes at the Lloyd, San Rocco, and San Marco shipyards in Trieste and Monfalcone. The wartime disruption of the port activities, as well as the postwar fragmentation of the former Habsburg economic space and its impact on the commercial routes through Trieste, had a severe effect on the workers' material conditions. They tried to retrieve their bargaining force, improve their salaries, and extend their social rights at the workplace while being pushed to struggle for more radical solutions by the revolutionary and Soviet myths. In several meetings held in March 1920, the Chamber of Labor discussed and finally approved the constitution of a soviet and of factory councils. ${ }^{47}$ The secretary of the local union, during a meeting of shipyard delegates, claimed that the workers in the industry were at the vanguard of the expropriation movement. ${ }^{48}$ However, there is no evidence of the implementation of plans of expropriation or the socialization of industrial plants in Trieste and its surroundings. As the police had to admit, "The masses, however, are still quite skeptical about whether so many Bolshevik promises can come true." 49

Nonetheless, the language and practice of violence were quite widespread within the working-class movement. In some cases, the Marxist vocabulary intertwined with an early twentieth-century culture, appealing to political will rather than to the laws of history and representing revolution as a generational change, an élan vital, a source of youth compared to an outdated "bourgeois" order. On this ideological basis, the Socialist Party organized the "Red Guards" (the arditi rossi), which in fact were intended to constitute the armed branch of the party in the event of an uprising. However, increasing disagreements concerning the nature of revolution, the form of the party and its relationship with the masses, and the legitimacy of the use of violence divided the Socialist Party. In the Julian March section, the Communist motion was approved by a majority of more than one thousand votes. In late January 1921, some Communists, headed by Tuntar and Regent, took over the Il Lavoratore typography. ${ }^{50}$ Additionally, they took the step of reorganizing the "Red Guards," who were willing to tackle the Fascists in the streets. ${ }^{51}$

In sum, social conflicts as well as the Socialists' radical rhetoric made "revolution" seemingly inevitable in post-Habsburg Trieste. From an opposing, albeit specular, position, the Fascists used the perceived revolutionary threat to legitimize their own aggression against Socialists and Communists. Nevertheless, as shown in the next section, the Fascist answer to the "Bolshevik" challenge was substantially grounded in a lengthy nationalist tradition, the experience and legacy of war, and the demise of the public authorities during the postwar period.

\section{Italian Nationalism and Fascist Radicalism}

It was no coincidence that the tensions that had been increasing since the very beginning of the Italian military occupation of Trieste broke out into violence simultaneously with the replacement of the

\footnotetext{
${ }^{46}$ Report by the Royal Civil General Commissioner's Office of Julian March to the Prime Minister's Office, Central Department for the New Provinces, 18 Apr. 1920, ACS, PCM, UCNP, busta 49.

${ }^{47}$ Report by the Royal Carabinieri, Trieste Division, 31 Mar. 1920, AST, RCGCVG, AG, busta 80.

${ }^{48}$ Report by the Royal Police Headquarters to the Civil General Commissioner's Office of Julian March, Trieste, 2 Apr. 1920, AST, RCGCVG, AG, busta 80.

${ }^{49}$ Report by the Royal Police Headquarters to the Royal General Civil Commissioner's Office of Julian March, 9 Mar. 1920, ACS, PCM, UCNP, busta 56.

${ }^{50}$ Telegram from the Vicecommissariato Generale Civile della Venezia Giulia (General Civil Vice-Commissioner's Office of Julian March), Trieste, 27 Jan. 1921, ACS, PCM, UCNP, busta 51.

${ }^{51}$ Report by the Royal Police Headquarters to the Royal Civil General Commissioner's Office of Julian March, 19 Aug. 1921, AST, RCGCVG, AG, busta 107.
} 
military authority by a civil one in early August 1919. In the aftermath of the Great War, the Italian-speaking National-Liberal group that had ruled late Habsburg Trieste was heading toward decline. This depended less on the achievement of the irredentist targets than on the radicalization of the political struggle, which had been reshaped by the violent legacy of the war, the postwar social movements, and the challenge of the Socialist Party.

New forms of radicalism emerged and especially involved the younger generations, who had only lived through the latter years of Austria-Hungary that were characterized by its final demise. At the time, Trieste was crowded with nationalist associations comprising both young radicals (several of whom were students) and veterans, such as the Sursum corda (an Italian irredentist association set up in 1908) and the Anti-Bolshevik Action Committee (Comitato di azione antibolscevico), ruled by the local radical nationalist Fulvio Suvich. On 3 April 1919, the Fascio di combattimento di Trieste was founded with the support of the civil commissioner Mosconi and the collaboration of representatives of the local political elites, such as Sergio Dompieri (son of Carlo Dompieri, liberal-national ex-mayor of Habsburg Trieste from 1897 to 1900). It held its first meetings at the headquarters of the Società Operaia Triestina (the Trieste Workers' Association). This association, founded in 1869, straddled late corporatism and early cooperativism; however, as it had been inspired by Mazzini and Garibaldi, it was opposed to international Socialism. D'Annunzio's illegal occupation of Fiume, from September 1919 to December 1920, had a radicalizing effect on Trieste too, acting as a catalyst for a great number of supporters seeking revenge for the so-called mutilated victory (vittoria mutilata). The Fascio of Trieste became a center for the recruitment of volunteers going off to fight in Fiume, and it set up the Comitato pro Fiume (Pro-Fiume Committee).

The Fascist movement made an active intervention in the Italian-speaking community of post-Habsburg Trieste, starting with the mobilization of the former regnicoli. Accordingly, it established a committee to help them with their everyday needs and to search for new jobs (Comitato per i regnicoli danneggiati dalla guerra). The Fascists complained that too many "Italians" were unemployed, while "foreigners" were given "systematic priority" with regard to jobs in public offices, factories, shipyards, and shipping companies. Thanks to their battle against "foreigners," the Fascist Party appealed in particular to demobilized war veterans, unemployed workers, and underpaid or marginalized civil servants. ${ }^{52}$ In this regard, it represented a kind of secret committee tasked with the "cleansing" of the civil service (Comitato per l'epurazione), inviting citizens to submit anonymous reports of "foreigners" or "non-Italians." In addition to the monitoring actions of the Fascist squads, "every Italian" was energetically encouraged to "open your eyes, be watchful, peek through the curtains, and denounce without scruple." 53

The increasing fear that the law enforcement agencies, military authorities, and radical nationalist networks had of losing control of the unstable borderland areas appeared to legitimize any sort of reaction against the purported "enemies of the nation." This is suggested by a Carabinieri report from July 1920, just after the assault on the Narodni Dom, that stated: "In recent months, the Slavic party has started concerted work on its irredentist propaganda, taking advantage of the anti-national action carried out by the official Socialist Party, of the economic crisis provoked by the war, and of the generosity of our institutions and authorities, in contrast with that of the past regime." 54 To be sure, the "Slavic party" mentioned here did not exist as such, and this picture tended to crystallize a political reality that was much more fluid and fragmented than was admitted. A nationalist Slovenian group was gathered around the daily Edinost, but it had no connections with the Socialist Party. Certain "Yugoslav" agents

\footnotetext{
${ }^{52}$ Report by the Fascio Triestino di Combattimento, dated 4 Feb. 1920, to the Royal Civil General Commissioner's Office of Julian March, Antonio Mosconi, ACS, PCM, UCNP, busta 56. Thanks, in particular, to the participation of regnicoli and other economic migrants from the kingdom, enrollment in the Fascist squads increased quickly, and by the end of spring 1921, the Federation of Trieste, divided into thirty-one sections, had 14,700 members. One year later, when the migratory flux diminished and many poor migrants were banished from Trieste, membership dropped to 10,500, divided into fifty-four sections.

${ }^{53}$ Francesco Giunta, "Manifesto," in Michele Risolo, Il fascismo nella Venezia Giulia. Dalle origini alla marcia su Roma, vol. 1 (Trieste, 1932), 53-55.

${ }^{54}$ Report by the Royal Carabinieri of Trieste, 3rd Division, Trieste, 16 July 1920, ACS, PCM, UCNP, busta 61.
} 
might have tried to conspire against Italian rule, or some nationalist beliefs might have driven certain Socialist or Communist activists. However, the idea that the Socialist Party was substantially inspired and guided by a "Slavic Party" in secret collaboration with the Kingdom of SHS with the purpose of overthrowing Italian rule was an inherent part of a conspiracy theory. It is impossible to say if the police authorities really believed in this simplified, polarized representation of the social reality of this multinational town, but it is clear that they acted accordingly, justifying active mobilization against the "enemies of the Italian nation."

However, in their will to struggle against those denounced as "foreigners," "Austrophiles," "Bolsheviks," and "Slavs," Fascists considered the repressive violence of the official institutions ineffective and insufficient. Accordingly, they decided to supplement the role of the state authorities with nonstate paramilitary organizations. The Fascist squads, set up in the spring of 1920, were organized according to a hierarchical structure of small gangs, headed by ex-servicemen and army officials. Not incidentally, it was a man from outside the borderland who managed to inject new energy into local Fascism. This was the aforementioned Francesco Giunta, a lawyer from San Piero a Sieve (close to Florence) who had taken part as a volunteer in the war. He had been a member of the main veterans' association (Associazione nazionale combattenti) and was the leader of the Alliance of Civic Defense (Alleanza di difesa cittadina), the original bulwark of Florence's Fascist squads. Giunta was convinced that the real battle against the "enemies of the nation" was fought in the new borderland. $^{55}$

Between 1920 and 1923, the Fascist squads unleashed a wave of attacks, ambushes, and selective murders. A combination of uncertainty and fear spread among the population, contributing to a real feeling of impending civil war. Conflicts between the Fascists and the Socialists/Communists especially took place in the shipyards and port areas of Trieste, Monfalcone, and Muggia, as well as in the adjacent working-class neighborhoods. A most bloody confrontation followed the general strike, culminating in the erection of barricades in San Giacomo/Sveti Jakob and violent struggles between Socialist activists and Fascist squads with the police forces, who were mostly willing to take sides with the latter. According to the police reports, these clashes were part of an "openly anti-national revolt," involving the "subversive masses, especially Slavs." 56 This revolt, which lasted from 6 to 10 September, led to some nine or ten deaths, seventy injuries, and more than five hundred arrests. The violence reached a peak in the weeks leading up to the first general election, held in May 1921. In this period, the offices of the Socialist newspaper Il Lavoratore and those of the Slovenian community's newspaper, Edinost, together with the Labor Exchange, were subjected to further assaults, acts of arson, and destruction.

As a matter of fact, a major novelty of the Fascist movement was its conception and use of violence to stir up the masses and, through the ensuing strife in the name of the "Italian nation," to set into motion the process of creating a new ruling class. Giunta defined Fascist violence as "a clever and necessary surgical operation ... at the service of a great ideal." ${ }^{57}$ Pietro Belli-a journalist of Popolo d'Italia from Spoleto who was close to Futurism and then Fascism and was involved in D'Annunzio's takeover of Fiume-emphasized the differences between pre-1914 nationalism and Fascism in terms of violent practices:

\footnotetext{
${ }^{55}$ See Dario Mattiussi, Il Partito Nazionale Fascista a Trieste. Uomini e organizzazione del potere, 1919-1932 (Trieste, 2002); Borut Klabjan, "Borders in Arms: Political Violence in the North-Eastern Adriatic after the Great War," Acta Histriae 26 (2018): 985-1002; Irene Bolzon, "La lunga durata dello squadrismo di confine. Comunità studentesche, società e pratiche della violenza a Trieste (1900-1945)," Geschichte und Region/Storia e regione 28, no. 1 (2019): 86-109.

${ }^{56}$ Telegram from the Royal Civil Commissioner's Office of Julian March, Trieste, 10 Sept. 1920, to the Prime Minister's Office, Central Department for the New Provinces, and to the Interior Ministry's Public Safety Department, ACS, PCM, UCNP, busta 81 .

${ }^{57}$ Francesco Giunta, L'essenza dello squadrismo (Rome, 1931), 6. For further historical considerations on Fascist violence see Adrian Lyttelton, "Cause e caratteristiche della violenza fascista: attori e fattori congiunturali," in Bologna 1920, ed. Luciano Casali (Bologna, 1982), 33-56; Mimmo Franzinelli, Squadristi. Protagonisti e tecniche della violenza fascista, 1919-1922 (Milan, 2003); and Sven Reichardt, Camicie nere, camicie brune. Milizie fasciste in Italia e in Germania (Bologna, 2009).
} 
Our violence is a warlike energy that we let blast only when it is needed to react to outrage and crime. Once upon a time the most pugnacious political associations, burning with faith, participated in the protest rallies and demonstrations, and they are still doing so today. Yet Fascism goes further. It directly targets the political enemy and its strongholds. ${ }^{58}$

This idea of targeted, merely reactive violence was part and parcel of Fascist self-representation. Its specific features in the northern Adriatic emerge against the backdrop of other paramilitary movements that shook Central Eastern and Southeastern Europe at the time (such as the Freikorps in the Baltic and Silesia, the Heimwehr in Austria, the Rongyos Gárda in Hungary, the Orjuna in Dalmatia, and the VMRO in Macedonia). Most of these groups conceived themselves radical nationbuilders in the so-called shatterzones of empire, where the state authorities had collapsed and the public monopoly of violence had been contested or overturned. ${ }^{59}$ In comparative terms, it is clear that the postwar crisis in the Adriatic "shatterzone" was not as violent and bloody as elsewhere in Central and Southeastern Europe. ${ }^{60}$ On the one hand, as in other postimperial multilinguistic border towns, the state authorities operating in post-Habsburg Trieste felt threatened by the majority of the local people they were nominally governing-hence the fragmentation of the increasingly weak public powers they exercised and the subsequent proliferation of political and paramilitary violence. ${ }^{61}$ On the other hand, taking place in a context in which the official authorities had declined but not collapsed, the Fascist practices engendered active sympathy and complicity among broad sections of the Italian police forces, regular army, and civil service, as the following report admitted: "Fascist extremists become increasingly undisciplined and are encouraged to perpetrate new acts of violence. Feelings of sympathy toward Fascists are spreading among the Royal Guards." ${ }^{\text {"2 }}$ Immediately after the march on Rome, the prefect of Trieste claimed that the local authorities in Julian March had acted against the Socialist and Communist parties "with unwavering strictness" and in a "patriotic" manner, and that "the crackdown on subversion that has been conducted subject to the rule of law" was "almost completed."

There can be no doubt that the very meaning of the rule of law, which had already been undermined by the Great War, was now being radically reformulated as a result of the broad support given by the police and army to the Fascist squads. In the prewar context of the rule of law, illiberal practices by the Habsburg authorities were designed to quell a growing number of demonstrations and strikes that went hand in hand with the growing political mobilization of the masses. ${ }^{64}$ Yet the Great War created unprecedented crises, which weakened the rule of law and the predictability and solidity of the Habsburg state. These crises were not the product of any long-term imperial decline but rather of the wartime state of emergency, which dramatically altered the character of the Habsburg Empire and the basis for its legitimacy. ${ }^{65}$ At the same time, the wartime actions of the Habsburg state against any form of treason exacerbated its pre-1914 illiberal features and bequeathed a track record of repressive provisions to the successor states. ${ }^{66}$ A sense of lawlessness, uncertainty, and unpredictability impaired the authority of the newly established Italian state and paved the way for political violence. Quite

\footnotetext{
${ }^{58}$ Pietro Belli, “Calma,” Il Popolo d'Italia, 4 Mar. 1921.

${ }^{59}$ See John Paul Newman, "The Origins, Attributes, and Legacies of Paramilitary Violence in the Balkans," in War in Peace, 145-63; and Newman, "War Veterans, Fascism, Para-Fascist Departures in the Kingdom of Yugoslavia, 1918-1941," Fascism 6, no. 1 (2017): $42-74$.

${ }^{60}$ For a similar consideration on Fiume see Dominique K. Reill, The Fiume Crisis: Life in the Wake of the Habsburg Empire (Cambridge, MA, 2020), 14-15.

${ }^{61}$ See Kate Brown, A Biography of No Land: From Ethnic Borderland to Soviet Heartland (Cambridge, 2003$), 13$.

${ }^{62}$ Telegram from the Royal Civil Commissioner's Office of Venezia Giulia, 2 Mar. 1921, ACS, PCM, UCNP, busta 51.

${ }^{63}$ Report by the Royal Police Headquarters, Trieste, 12 Nov. 1922, AST, Prefettura di Trieste, Gabinetto, 1923 , busta 34.

${ }^{64}$ Claire Morelon, "Social Conflict, National Strife, or Political Battle? Violence and Strikebreaking in Late Habsburg Austria," European History Quarterly (2019): 650-76.

${ }^{65}$ John Deak and Jonathan Gumz, "How to Break a State: The Habsburg Monarchy's Internal War, 1914-1918," American Historical Review 122, no. 4 (2017): 1105-36.

${ }^{66}$ Mark Cornwall, “Treason in an Era of Regime Change: The Case of the Habsburg Monarchy," Austrian History Yearbook 50 (2019): 124-49.
} 
paradoxically, while being the main promoter of chaos, the Fascist movement struggled to build a new sense of state authority and loyalty. ${ }^{67}$

Fascism succeeded in forming strong links with regional Italian-speaking nationalism, and it became a powerful catalyzer of ex-irredentists and nationalists. For instance, Fulvio Suvich, a lawyer from Trieste who volunteered in the war on the Italian side, was elected within the nationalist group in Parliament in 1921 before subscribing to Fascism, and Bruno Coceancig (then Coceani), a journalist and teacher from Monfalcone who volunteered in the Italian army, worked as head of the propaganda office under Petitti di Roreto's government and led the Triestine section of the Italian Nationalist Association until 1923, when he became political secretary of the Fascio. However, Fascism cannot be simply identified as a new form of nationalism, as radical as it may be. In a transitional context in which national identifications-as well relations between the majority and minorities-were still in the making, the call to Fascism was potentially addressed to all those who were willing to switch loyalty from the former state to the new one, regardless of their previous political positions. The only "true Italians" were the Fascists in this radically new perspective. As Silvio Benco, a nationalist journalist from Trieste, explained, Fascism did not possess "the rigid, aristocratic structure of the theories of nationalism" but rather "their emotional content." "It has become," he said, "as a result of the temporary indeterminacy of its political program, a focal point for different groups subscribing to a nationalist philosophy." 68

From the very start, Triestine Fascism represented a strange mix of localism and nationalism; that is, often the language of nationalism was used to challenge the liberal national governments. In February 1920, the local Fascio advocated even the administrative autonomy of the region and of the town, claiming that "the centralized bureaucracy has intruded upon the new provinces by paralyzing the flexibility and weakness of local offices through the excessive intervention of government ministers in Rome." ${ }^{69}$ Nevertheless, Francesco Giunta believed that it was high time "to get rid of the Austrian continuities." ${ }^{\prime 70}$ In January 1922, Giunta demanded the abolition of the Central Department for the New Provinces and the resignation of its head, Salata. The following October, just before the appointment of Benito Mussolini, the founder and leader of the Fascist movement, as premier, the Italian government decided to abolish said department, and in doing so rejected any real form of autonomy for Trieste and the Upper Adriatic. At the end of 1922, administrative standardization was definitively achieved through the closure of the General Civil Commissioner's Office and the establishment of the Prefecture.

\section{Nationalism as a Political Tool}

By building upon Max Weber's categories, Brendan Karch, in his study of German and Polish nationalisms in Upper Silesia, has proposed a fascinating distinction between a "value-driven stance to nationalism" and an "instrumental stance to nationalism" to frame the everyday relationship between committed nationalist activists and their more skeptical audiences. ${ }^{71}$ While the former concerns the legitimation of political action through nationalism, the latter refers to the social uses of nationalism. Upon closer examination, however, an excessively rigid distinction between ends and means may neglect the different ways of conceiving of politics - that is, on the one hand, as a project and practice

\footnotetext{
${ }^{67}$ See, for instance, Pietro Marsich, "Il Fascismo e lo Stato. Il contenuto politico del Fascismo," Il Popolo di Trieste, 26 Jan. 1921; Gino D’Angelo, "L'autorità dello Stato," Il Popolo di Trieste, 21 July 1921; Giovanni Cobolli Gigli, "Il fascismo e gli allogeni” in "Nove anni dopo l'armistizio. La Venezia Giulia. Quello che sognammo e quello che è," Gerarchia (1927): 303-6.

${ }^{68}$ Silvio Benco, "I partiti nella Venezia Giulia," L'Azione, 29 June 1920.

${ }^{69}$ Report by the Fascio Triestino di Combattimento, 4 Feb. 1920, to Civil Commissioner Antonio Mosconi, ACS, PCM, UCNP, busta 56.

${ }^{70}$ Francesco Giunta, “O noi o loro!,” Il Popolo di Trieste, 1 Apr. 1921.

${ }^{71}$ For the notion of instrumental nationalism, see Brendan Karch, Nation and Loyalty in a German-Polish Borderland: Upper Silesia, 1848-1960 (Cambridge, 2018). For the Upper Silesian case see also Timothy K. Wilson, Frontiers of Violence: Conflict and Identity in Ulster and Upper Silesia, 1918-1922 (Oxford, 2010); Tomasz Kamusella, James E. Bjork, and Timothy Wilson, eds., Creating Nationality in Central Europe, 1880-1950: Modernity, Violence, and (Be)longing in Upper Silesia (London, 2016).
} 
for broader collective purposes and, on the other hand, as a strategy for everyday needs. In fact, the differences between the nationalist views of politicians and activists and popular attitudes to nationalism were more a matter of contextual usage than of ideal-typical forms. Furthermore, such usage entailed diverse degrees of involvement in and commitment to the nation: compared to the activists, ordinary people's mindsets and behaviors were more likely to lean toward varying degrees of apathy, disloyalty, and indifference to nationalism. Paradoxically, an instrumental stance on nationalism is particularly evident when it comes to forms of political radicalism such as Fascism. ${ }^{72}$ This doesn't mean to underrate nationalism as a set of languages, values, myths, and emotions, but rather to consider how it coalesced into a set of polarizing strategies of intervention on political and social reality with various purposes-among which the most relevant was that of imposing a new sense of state authority and loyalty.

Until the summer of 1920, the Socialist Party was the major political force in the northern Adriatic. Nevertheless, the working-class movement, full of workers who had recently moved to Trieste from the surrounding countryside, was characterized by a variety of local dialects and loyalties and by people's readiness to switch political allegiances from one side to another. In fact, the rivalry between Fascists and Socialists exploded when the Fascio, on the basis of its "eminently national program," launched its own "union action" that strongly affected the working-class movement. Certain "national unions" promoting measures based on a blend of Socialism, Triestine localism, and Italian nationalism had undoubtedly already taken place prior to $1914 .{ }^{73}$ However, the post-1918 context rendered the new actions explosive. While opening the employment exchange in Monfalcone, the Fascist Piero Dagnino, ex-captain of the Italian military elite troops Arditi, set up the Italian Chamber of Labor in Trieste. More than eight thousand members of the Socialist Party who refused to take part in the general strike of September 1920 were expelled from the Socialist union, and some of them joined the new Fascist union. Mussolini claimed that in the port areas of Trieste, "thousands and thousands of 'authentic' workers" had joined the "national unions." Within a very short period of time, the Socialist Party, which had succeeded in "exercising real hegemony not only over the working class but also over certain categories of bourgeoisie and intellectuals," was faced with "the desertion of more than a thousand workers." The Fascists' battle against the Socialists was carried out in the name of an agenda for the organization of corporations and professional unions: "The huge economic and social questions currently affecting the Italian proletariat, and which have led to public disorder in many regions of Italy, have here impacted people already troubled by local issues and questions of nationality." 75 As a result, the violent struggle between Fascists and Socialists paved the way for a radical reconfiguration of social relations and political allegiances in the industrial areas of Trieste, as emphasized by a November 1922 police report:

In keeping with the opportunism common to any period and to any political and historical event, the masses have followed the victor: today we have seen a deluge of subscriptions to the new National Labor Unions, by the very same workers who were members of the "Red Leagues" until just a few days ago. This phenomenon, which has happened too quickly, could raise concern among the leaders of the new Unions, who have not had the time to identify recently enrolled members, and who now must shoulder the burden of addressing and satisfying the aspirations of a huge number of new followers still bewildered by Bolshevik theories. ${ }^{76}$

According to Giorgio Chiurco, a native of Istria who wrote an apologetic history of Fascism, by 1922 the "national unions" in Trieste had been joined by as many as twenty thousand new members defecting from the Socialist unions, people working in a variety of different areas reorganized by the policies

\footnotetext{
${ }^{72}$ As Karch suggests, the "feedback loop between national radicalism and instrumentalism reached a new pitch" with the ascent of Nazism to power in the early 1930s (Karch, Nation and Loyalty, 219).

${ }^{73}$ Ennio Maserati, Il movimento operaio a Trieste dalle origini alla prima guerra mondiale (Milan, 1973), 214-70.

${ }^{74}$ Benito Mussolini, "Il meraviglioso movimento fascista della Venezia Giulia,” Popolo d'Italia, 24 Sept. 1920.

${ }^{75}$ Report of the Royal Civil Commissioner's Office of Julian March, 14 Sept. 1920, AST, RCGCVG, AG, busta 81.

${ }^{76}$ Report by the Royal Police Headquarters of Trieste, 12 Nov. 1922, AST, Prefettura di Trieste, Gabinetto, 1923 , busta 34.
} 
of "purge" (the timber industry, railways, post offices, port authorities, and shipyards). ${ }^{77}$ These numbers cannot be considered completely reliable. However, a substantial transition of former Socialist union members into Fascist organizations took place against a backdrop of widespread Fascist violence and the split between Socialists and Communists. ${ }^{78}$ After Mussolini came to power, the workforce in Trieste, "already distraught by rising unemployment and by the failure of political strikes" organized by the Chamber of Labor, revealed "signs of tiredness and discouragement." As a result, "many members of the former Communist Party" switched allegiances to the "national unions [that is, the Fascist unions] if not for sentiment, for personal gain."79

Under the pressure of Fascist violence, some people from different social classes tried to exploit an unexpected series of opportunities, which they were eager to grasp at any cost, in hope of stemming the loss of their previous economic security, improving their job position, and actively participating in the establishment of a "new order." Within the new institutional context, alongside the processes of "purge" and migration, significant changes occurred also in regard to the self-identification process, compared to the late Habsburg period. The 1921 census figures show that 198,886 out of a total of 228,583 inhabitants of the municipality of Trieste, declared themselves Italian speakers, and 11,694 declared themselves Slovenian speakers. (Nonetheless, 11,628 among these Slovenian speakers also claimed to be able to speak Italian. $)^{80}$ It is thus possible to argue that after the regime change some "national" identifications might be instrumental in legitimizing claims to a better economic or social condition. ${ }^{81}$ On the one hand, the language of the nationalistic conflict took it for granted that there was a divide separating "Italians" from "Slavs"-one that had tended to conceal or minimize the alleged division between "Italian workers" and "Slavic workers." On the other hand, the social and economic nature of the troubles witnessed in Trieste became the grounds for political competition between Socialists and Fascists. The Socialist and Communist identification with the "Slavs" provided the Fascists with an extraordinarily powerful rhetorical weapon with which to gain room for maneuvering within the working-class movement, as they then claimed to represent "Italian workers." In this regard, rather than representing a mere knee-jerk reaction of existing communities, the language of national confrontation between "Italian workers" and "Slavic workers" became a flexible and effective means of both separating the working-class population from the Socialist and Communist parties and shaping its sympathy and loyalty toward the rising Fascist movement and unions. ${ }^{82}$

During the second half of 1924, following the murder of the Socialist leader Giacomo Matteotti, the Fascists' mobilization of workers declined significantly and the number of sympathizers for the Communist Party increased again. The destabilizing backlash of the Matteotti affair undermined the enlistment to the Fascist unions, not only among the construction workers and the tram drivers but also-and especially-among the metallurgical workers and steel workers. ${ }^{83}$ However, from 1925 onward, the establishment of Mussolini's dictatorship swept aside any form of open opposition.

\footnotetext{
${ }^{77}$ Giorgio Chiurco, Storia della rivoluzione fascista. 1919-1922, vol. 5 (Firenze, 1929), 343.

${ }^{78}$ Aldo Oberdorfer, "Qualche perché della débacle socialista nella Venezia Giulia," Critica sociale, 19 (1921): 296.

${ }^{79}$ Report by the Royal Police Headquarters, Trieste, 17 Jan. 1923, AST, Prefettura di Trieste, Gabinetto, 1923, busta 42.

${ }^{80}$ See Ministero dell'Economia Nazionale - Direzione Generale della Statistica - Ufficio del Censimento, Censimento della popolazione del Regno d'Italia al I dicembre 1921. III. Venezia Giulia (Rome, 1926), 198. A total of 18,003 people were defined as "foreigners"; that is, without Italian citizenship.

${ }^{81}$ For instance, a ticket inspector of the Triestine tramways, a certain "Camillo Deovic," in spite of his "Croatian origin" from Dalmatia, had become "a Fascist" after being imprisoned in wartime Trieste as a deserter from the Habsburg army (see "Un austriacante autentico," Il Lavoratore, 5 Nov. 1921).

${ }^{82}$ Tellingly, in September 1920 the Municipal Executive Committee asked the Fascist leader Roberto Farinacci to leave his native Cremona to take on a leading position in the fight between "Italians" and "foreigners" in the borderland of Trieste, where the "Slavs" were exercising "terrible pressure": "A stubborn battle is required to separate Italian workers (and many of them right here, in the face of foreigners, once again feel the superiority of their race and the call to battle that inevitably sets one race against the other) ... from the leaders of the Pus (Partito socialista unitario)." Municipal council letter to the Fascist Central Committee, 10 Sept. 1920, ACS, Museo della Rivoluzione Fascista, busta 42, Trieste.

${ }^{83}$ Report by the Royal Police Headquarters, Trieste, 12 Sept. 1924, AST, Prefettura di Trieste, Gabinetto, 1924, busta 75.
} 


\section{Conclusion}

The prevailing narratives of the rise of Fascism in the Upper Adriatic have elaborated on an essentialist conception of national categories and have linked the long-term "national strife" between "Italians" and "Slavs" to the post-1918 crisis. Nevertheless, by adopting a critical stance toward such narratives, this essay has attempted to explain the extent to which the post-Habsburg crisis in Trieste was shaped by problems of imperial transition and transformation. Until 1922 at least, the new authorities' nationalizing and centralizing policies were countered by a series of different, even opposing trends. A deeprooted perception of continuity, in spite of the regime change, surfaced from the partial reintegration of the Habsburg bureaucracy into the newly established one, as well as from the persistence of the political culture and practices of Habsburg Trieste. Furthermore, everyday economic requirements and demands fed waves of social struggle and conflict that tested the new authorities and sometimes questioned their legitimacy. In this tense context, Russian revolutionary/Bolshevik myths radicalized the ascending Socialist (and subsequently Communist) movements as they tried to overcome national divisions in the name of internationalism.

As explained at the beginning of this essay, the July 1920 attack on the Narodni Dom by Fascist squads seemed to epitomize the clash between "Italians" and "Slavs." Nevertheless, such interpretation tends to obscure two crucial aspects that this essay has tried to highlight. On the one hand, Fascists in Trieste, by supporting the regnicoli's claims and interests, promoted a political strategy that violently divided the local community from both within and without. On the other hand, Fascists in Trieste, by increasingly catalyzing local Italian nationalists and ex-irredentists, were able to gain power over the city's continuous (albeit declining) multilingual and multicultural society with the goal of radically reshaping it. Fascist radicalism stemmed from the sense of belonging to a minority perceived as besieged by "Slavism" and "Bolshevism" and battling against all apparent traces of "Austria" in Trieste. It appropriated the language of Italian nationalism against the "Slavic" groups and "Bolshevik" movements, using it to legitimize mass mobilization through the claim that the Fascists represented "true Italians." The representation of "anti-national" forces pitted against "national" forces was a rhetorical ploy designed to identify and delegitimize the Fascists' enemies in post-Habsburg Trieste. Through their battle against enemies they labeled as "Slavs," "Bolsheviks," "Austrophiles," and "foreigners," the Fascists not only managed to destroy the Socialist and Communist movements but also to mobilize parts of those movements' grassroots bases. Thanks to the complicity of Italian institutions perceived as weak and powerless, they imposed a new (Fascist) sense of state authority and loyalty. ${ }^{84}$

In spite of the peculiarities of Fascism's rise in a post-Habsburg setting like Trieste, this case study has more general implications for twentieth-century Europe (and beyond). As the sociologist Michel Dobry has argued, political crises have nothing pathological in themselves and are explicable in terms of continuity rather than drastic change. In a context of political uncertainty and contingent fluidity of social relations, the crucial factor is played by the mobilization of the resources on the part of the involved actors for pursuing strategic and tactical goals. ${ }^{85}$ As shown in the case of post-Habsburg Trieste, in conditions of decline of the rule of law, radical rightist movements implement a series of polarizing strategies of intervention on everyday political and social reality-strategies that can be dramatically effective in fostering conflict, opposing and fighting alleged enemies, and pitting social groups against one another. Accordingly, they tend to trigger destabilizing situations of crisis and produce unpredictable outcomes-even the imposition of a new regime, as in the case of Italian Fascism.

\footnotetext{
${ }^{84}$ As specific as they were, these dynamics of the rise of Fascism in the Upper Adriatic were comparable to those seen in other Italian regions: see Salvatore Lupo, Il fascismo. La politica in un regime totalitario (Rome, 2000); and Paul Corner, Italia fascista: politica e opinione popolare sotto la dittatura (Rome, 2015).

${ }^{85}$ See in general Michel Dobry, Sociologie des crises politiques. La dynamique des mobilisations multisectorielles (Paris, 1986); and more specifically Dobry, "Desperately Seeking 'Generic Fascism': Some Discordant Thoughts on the Academic Recycling of Indigenous Categories," in Rethinking the Nature of Fascism: Comparative Perspectives, ed. António Costa Pinto (London, 2011), $53-84$
} 
Acknowledgements. The author thanks, alongside the two anonymous reviewers, Laurence Cole, Ivan Jeličić, Claire Morelon, John Paul Newman, Mila Orlić, Dominique K. Reill, and Rok Stergar for their insightful comments and suggestions on earlier versions of this article.

Marco Bresciani is Research Fellow in the Department of Political and Social Sciences at the University of Florence. He received his $\mathrm{PhD}$ from the University of Pisa, and he has obtained several fellowships in Italy and abroad. His main research fields are the political and intellectual history of Italian and European Socialism, antifascism, and antitotalitarianism, as well as the political and social history of the post-Habsburg Upper Adriatic and of the postwar ascent of Fascism. His most recent publication is the edited volume Conservatives and Right Radicals in Interwar Europe (London, 2021).

Cite this article: Bresciani M (2021). The Battle for Post-Habsburg Trieste/Trst: State Transition, Social Unrest, and Political Radicalism (1918-23). Austrian History Yearbook 52, 182-200. https://doi.org/10.1017/S0067237821000011 